\title{
Iraqi Prisoners in Norway: Educational Background, Participation, Preferences and Barriers to Education
}

\author{
KARIANE WESTRHEIM AND TERJE MANGER
}

University of Bergen, Bergen, Norway

\begin{abstract}
The article aimed to develop knowledge of the educational background, participation and preferences of Iraqi prisoners in Norwegian prisons and obstacles to participating in education. The study is based on interviews with 17 prisoners in three prisons. An important finding is that war and political unrest appear to have been significant causes for respondents to leaving education at various stages. As a result only half of them have as much as one final exam and only three respondents have a certificate of education. Even if the respondents want an education while in prison, and although education is offered in all prisons, there is a lack of information about educational opportunities in an understandable language and long waiting time for a place at school. An implication of the study is that the criminal administration system and the educational authorities must take into account the multicultural reality by facilitating education and training offers accordingly.
\end{abstract}

Keywords: Iraqi prisoners; adult education; educational barriers; future plans; Norway.

\section{Introduction}

The study underpinning this article is aimed to develop knowledge of the educational background, participation and preferences of Iraqi prisoners in Norwegian prisons and what they perceive as barriers to their education in prison. The study is based on data from one of five Nordic qualitative studies following up several large quantitative national Norwegian and Nordic studies carried out in 2004, 2006, 2008 and 2009. The quantitative studies show that many ethnic minority prisoners lack sufficient education for various reasons, among others due to insecure backgrounds from their home countries. In the Norwegian survey in May 2009, it emerged that 10 percent of all prisoners had not completed any education and that foreigners were overrepresented. A lack of education represents a major challenge for Prison and Probation Services and the training offered by this service with regards to designing the educational opportunities to individual prisoners. Research-based knowledge is important in the forming of good, structured and adapted educational offers that meet the target group's needs.

Studies show that the proportion of foreign citizens in Norwegian prisons doubled from 2006 to 2009 (Eikeland, Manger, \& Asbjørnsen, 2010) and constitutes about 30 percent of the prison population (The Norwegian Correctional Services, 2014). The prisoners speak different languages and have different social, cultural and economic backgrounds, even when some of them come from the same country. Iraqi prisoners were selected as a target group for the current study because they constitute one of the largest groups of foreign prisoners in Norway, and also because they represent a group whose education has been seen in a context of war and suffering. Research shows that the educational system is among the hardest hit in war and conflict, and that it is used systematically by authorities and power groups to gain control over, indoctrinate or assimilate all or parts of the population (Bush \& Saltarelli, 2000; Hanemann, 2005; Machel, 2001). It is therefore probable that the prisoners from Iraq are affected in different ways by such events. We will therefore seek to examine how this context of war, conflict and suppression has influenced their school background and individual courses of education to different degrees. For the prison staff and teachers in prison it is important to know more about the consequences for future learning of interrupted schooling and flight from war. Most of these consequences will be negative but may also include a competence among the individual prisoners that teachers should not oversee. Also, prisoners' memories from war, fear and lack of concentration will influence present learning and have consequences for the student-teacher interactions and activities in the classroom.

\section{Legal and humanistic reasons for offering education in prison}

Prisoners have the same rights, as other citizens, to education and training. These rights are regulated by international conventions and recommendations, and this also applies to foreign citizens in Norwegian and other Nordic prisons. The Nordic countries have incorporated the European Human Rights Convention into their legislation. It is stated in the first protocol, article 2: "Nobody will be denied the right to education" (cf. Høstmælingen, 2004, p. 313). In Norway this implies that prisoners are entitled to seven years of mandatory 
primary school, three years of mandatory lower secondary school, and three years of non-mandatory upper secondary school, which has three branches (general, mercantile, and vocational).

Although the right to education is non-negotiable, in Norway there is a dispute over the ethnic minority prisoners' rights. Who has full rights to education, and who can only partially benefit from the education services? Eikeland, Manger, Gröning, Westrheim, \& Asbjørnsen (2014) conclude that given a common interpretation of education law in Norway, international conventions and recommendations and basic legal and humanistic principles, prisoners are entitled access to education in the same manner as other citizens and residents, independent of their nationality and a possible deportation decision. According to the Norwegian Directorate of Immigration (UDI) 1,700 people were expelled for violation of the Immigration Act in 2011. Many were expelled because they gave incorrect information in their applications or because they had stayed in Norway without a permit. Iraqis, Somalis, Serbs and Afghans were the nationalities most commonly expelled. As a main rule the decision implies that the foreign national is registered in the Schengen Information System (SIS) and that he orshe will be prohibited from entering the Schengen-area for a given period of time (Norwegian Directorate of Immigration Annual Report, 2011).

As well as the legal reasons for education and training in prison, there are humanistic reasons. All members of every society should receive education because of its own intrinsic value. It develops the whole personality, provides experience of mastering skills and protects a person's dignity. A person's opportunity to receive an education is a litmus test of how democratic a society is. There is a serious threat to democracy inherent in the exclusion of individual groups within society from the educational system and in their marginalisation or prevention from participating in education and training. A sustainable democracy is conditional on knowledge and participation (Westrheim, 2012). In order to achieve this, everybody must participate on the basis of their circumstances, including those who are serving a prison sentence. The humanistic justification for prisoners' entitlement to education was well summarized by Kevin Warner, former coordinator of prison education in Ireland, in his contribution to the eighth conference for European directors and coordinators for prison education in Lucerne, Switzerland, in 2010:

The importance of thinking of clients in prison as they are: people with faults like the rest of us, but also with richness of personality and undeveloped potential (in other words, as "whole persons" rather than just as "offenders").

The humanistic ideal has governed our legislation and international conventions and recommendations. The humanistic and legal grounds for education are often downplayed when compared with the more obvious justification, which is that education may reduce return to criminality, or recidivism, and facilitate adjustment to the workplace. Of course the latter reasons are im- portant and a range of studies (e.g., Davis, Bozick, Steele, Saunders, \& Miles, 2013) show that education has a significant and positive effect on recidivism. If however, in the worst-case scenario, it emerged that the effects of education on recidivism were slight, the humanistic argument still maintains that education and training in prison is a right in every society.

\section{Prisoners' educational background, participation, preferences and barriers against education}

Several studies show that the educational background of prisoners tend to be very poor (e.g., Hetland, Eikeland, Manger, Diseth, and Asbjørnsen, 2007; Tewksbury and Stengel, 2006), but they also show that prisoners want to participate in education during incarceration and that a majority prefer vocational education or courses (Eikeland, Manger, \& Asbjørnsen, 2009). The need for education also has to be seen in the context of whether prisoners themselves experience barriers and obstacles in starting an education in prison. In Norway more than half of the prisoners with Norwegian citizenship participate in education, but more than four out of five wish to participate while incarcerated. Among barriers to start an education is the short sentence time, lack of information about education, preference for work during incarceration, or that the education they are interested in is not offered in the prison (Eikeland, Manger, \& Asbjørnsen, 2013).

In recent years there has been a significant increase in immigration to Norway, especially immigration for work (Henriksen, Ostby, \& Ellingsen, 2010). On January 27, 2011 the prison population in Norway included 31.6 percent foreign nationals from 99 countries. At the time the largest groups were from Poland (131), Lithuania (111), Nigeria (80), Iraq (73), Romania (56), and Somalia (52) (Ministry of Justice and the Police, 2011). Findings from five national surveys in the Nordic prisons clearly show that ethnic minority prisoners, independent of background and nationality, are motivated for education and training. However the main obstacle appears to be a lack of information or inadequate information in their mother tongue (Eikeland, Manger, \& Asbjørnsen, 2009). A recent study (Eikeland, Manger, Gröning, Westrheim, \& Asbjørnsen, 2014) shows that only 35 percent, 26 percent, and 38 percent of prisoners in Norway from Lithuania, Poland and Nigeria respectively, participate in prison education. However between 75 and 93 percent of the prisoners from the three countries want to participate and most often want to attend non-vocational courses, such as language or computer courses. Contrary to the Norwegian prisoners, their main reason for not participating is that they are waiting for a place in school or on a course. Nevertheless, lack of information about education is also seen as a major problem. When the prisoners from these three countries are released about 80 percent of them want to get a job or continue in their previous job.

Of the 547,000 immigrants in Norway, 21,000 are from Iraq and of those 6,400 are Norwegian-born people, with parents who emigrated from Iraq. Most re- 
spondents in this group are Iraqi-born and have attended school in Iraq. A smaller number have grown up in Norway and attended school in Norway. Young people with parents from Iraq are almost completely unrepresented in higher education in Norway (Støren, 2006, reproduced in NOU 2011:14, p. 172). To understand the particular background of ethnic minority prisoners from Iraq, it has been important to look at contextual circumstances, such as the educational system, political and economic circumstances. The Iraqi educational system is briefly described below.

\section{The educational system in Iraq}

The educational system in Iraq was influenced by Western educational systems over many years. Even today it does not have an identity rooted in the cultural, religious and linguistic minorities in the area. In general, Arabic is the official educational language. An exception is the Kurdish autonomous region in the north, where the educational language is mainly Kurdish-Sorani. The Kurdish language has been fractured into different dialects, alphabets and statuses and gained official status in Iraq after the US-led invasion in 2003 (Sheyholislami, 2010).

As in many other countries around the world, higher education was reserved for the sons of the elite, while girls and women had little or no access to schooling or higher education. Paradoxically enough, this changed when the Ba'ath party seized power in 1968, with Saddam Hussein in charge. Despite Saddam Hussein's atrocities, the educational system flourished in the beginning of the regime, in a country where nearly 90 percent of the population were illiterate (Ranjan \& Jain, 2009). There were also measures to get women into education (Issa \& Jamil, 2010).

In the period from 1970 to around 1990, the educational system in Iraq was considered to be one of the best in the Middle East with regard to access, competence, quality and gender equality. According to World Education Services (WES, 2004) what was achieved in the period between 1970 and the end of the 1980s was destroyed as a result of the regime, cutting funding and becoming increasingly oppressive, controlling and brutal.

In the years following the US invasion in 2003 and as a result of destructive acts of war and political indecision, around 80 percent of all educational institutions were destroyed (Issa \& Jamil, 2010; Ranjan \& Jain, 2009). This led to a renewed increase in illiteracy (UNESCO, 2003). The improvements that have been carried out since the invasion in 2003 have primarily benefited Baghdad and the Kurdish autonomous region in the North. It must be emphasised that improvements have been implemented in Iraq since 2007, but there are still huge challenges in all sectors, including education.

\section{Research problems}

The purpose of this study was to gain knowledge about Iraqi prisoners' educational background, preferences and needs for education. With this background the following research question was posed: What are the educational backgrounds of Iraqi prisoners in Norwegian prisons, and what preferences and needs do they have? As part of the main question we were also interested in how political and war-ridden circumstances influence the respondents' education in the home country and what are the consequences for education in prison? Likewise, we sought knowledge about factors that the prisoners consider to be barriers for starting an education in prison.

\section{Methodical Approaches}

It is often presumed that prison is a problematic place to conduct research (Waldram, 2009; Liebling 1999). Researchers have, over many years, considered and written of the challenges that can arise in this field of study. Several researchers describe the complexity of conducting field work in prison and the problems and dilemmas that may occur when the researcher carries out qualitative interviews with prisoners (cf. Achermann, 2009; Bosworth, Campel, Demby, Ferranti, \& Santos, 2005; Liebling, 1999; Lowman \& Palys, 2001; Newman, 1958; Quina et al., 2007; Schlosser, 2008; Waldram, 1998, 2009). What we experienced though were encounters with highly motivated prisoners who willingly shared their views, experiences and stories about their background, educational history, their life in prison and future perceptions. Many respondents would probably have wished to spend more time with us, not only because the interview was a welcome relaxation from their daily routine in prison, but also because they finally had the chance to talk about themselves.

\section{The respondents}

The study referred to in this article is based on 17 qualitative interviews with male prisoners from Iraq, and was carried out in three Norwegian prisons in the period from February to April 2011. The youngest respondent was born in 1990, the oldest in 1963. Six were under 25; six were aged from 26 to 39; and five were over 40. All respondents were born in Iraq to parents also born in Iraq. They come from different cultural, linguistic and social backgrounds and most of them (12) are from the northern autonomous region of federal Iraq - the Kurdistan Region. Four respondents are from other parts of Iraq, and their mother tongue is Arabic. One of 17 belongs to another ethnic group that makes up about 3 percent of the population. Nine of the interviewees came to Norway alone and had no family in Norway prior to their arrival. Some had spent time in other European countries before coming to Norway. Four arrived with other family members, and two of them had attended school in Norway: one completed lower secondary school, while the other completed upper secondary school. Five respondents have established their own families with their own children in Norway or been reunited with their wives or children from Iraq.

Geographically, the prisons are divided between three places in eastern Norway and have varying degrees of security, from open to secure units. According to the 
Ministry of Justice and Police (2011) a total of 73 Iraqi citizens were incarcerated in Norwegian prisons at the time, and little was known about this particular group of prisoners. From the interviews it emerged that the length of the sentences they received varied from a couple of months to many years. At the outset we planned to interview prisoners of both genders. However this was not possible since there were no women of Iraqi background in the three prisons where the interviews were conducted. Statistics from Norway show that the prison population in total consists of only 5-6 percent women (Eikeland, Manger \& Diseth, 2006; Eikeland, Manger, \& Asbjørnsen, 2009, Eikeland et al., 2010).

\section{The interview guide}

The first part of the interview guide contained structured questions (items) ordered according to topic. Questions were asked about the prisoners' educational background and work, educational preferences, teaching language and educational barriers. The questions were asked by the interviewer, and the answers were noted by her. The respondents were free to answer the open-ended question based on their own background and context.

The second part of the interview guide contained structured questions and was a follow-up of the open questions connected to language and social and cultural capital. The structured questions and the respondents' alternative answers were either noted by the interviewer or by the respondent - all according to the prisoner's preferences and ability. Even though these questions were structured, it was important to note the respondent's thoughts and stories relating to these questions if he was willing to reveal them. The researcher was open to the fact that the respondent could supplement or expand the questions with information that was important for them to share with the researcher.

\section{The interviews}

As mentioned above, data was gathered through structured and semi-structured interviews. Some interviews developed into what can be termed in-depth interviews. The individual respondent was selected in advance according to determined sampling (Silverman, 2001). Otherwise, the respondents consisted of those prisoners that agreed to participate.

In two prisons the interviews took place in the visitor's room, and in the third prison (open prison), we used a classroom. Besides the respondent, there were three persons present in the first and largest prison: the researcher (female) who conducted the interview, the interpreter (male) who was a teacher by profession and spoke Arabic and Kurdish fluently, in addition to English and Norwegian. Much has been said about the role of the interpreter in interview settings, but the impression was that the presence of the interpreter did not bias the results of the study in any way. On the contrary the interpreter was appreciated among the respondents who were sceptical to the use of an interpreter prior to the interviews (this is also mentioned in the next section).
The third person present (female) holds a Master in Education, and was engaged as research assistant in this particular project. She recorded and transcribed the interviews. In the second and third prison only the researcher (interviewer) and the interpreter were present. The researcher recorded the interviews which were later transcribed by the research assistant. The prison staffs accompanied the respondents to and from the interviews but were not present in the interview room at any time. The interviews also took place out of sight and sound of the other prisoners.

The interviews lasted between one and a half and two hours and proceeded without any particular problems. In one case we were presented with an ethnic minority prisoner who willingly told us about his educational background. When it emerged that he was not from Iraq and was therefore transported back to his cell, he expressed disappointment that he could not continue the conversation. This can be regarded as confirmation that prisoners experienced the conversation with the researcher as positive and that educational issues were something they had never previously discussed in prison. As well as answering the questions in the interview guide, the prisoners also brought up topics and ideas that preoccupied them. Some had very emotional reactions to a number of topics, for example becoming tearful when talking about a much loved teacher. Nevertheless, they all appeared to be in control of the situation. During the interviews the interviewer asked some extra questions in order to encourage the respondent to narrate their "story". Nearly all respondents took the challenge and invited the interviewer to share with them their memories of schooling and of how their educational development progressed in a country heavily ridden by war. This unexpected dialogue created a form of closeness between the interviewer and prisoner which in line with Schlosser (2008), could be termed "identity moment"; a situation specific, contextual, lifechanging phenomena of moments which can be experienced only when respondent and interviewer are in dialogue with each other. So perhaps, according to Liebling (1999), the most interesting data occur when researcher and the prisoner dare to exceed their roles.

\section{Ethical challenges and approval}

A particular ethical challenge relates to the use of interpreter, as is the case in this study. People who come from areas dominated by war or political conflict, will in some cases, according to the circumstances, be sceptical of or suspicious towards a third person from the same country, unless that person is selected by the respondent himself. In this study we discussed this matter with the interpreter in advance. The interpreter's task was to translate the interview guide, the information documents and the declaration of consent into the languages which we assumed were the mother tongues of at least some of the respondents. The interpreter was experienced and had a professional background in pedagogy, so the topics of the interview guide were not unfamiliar to him. In this study the researcher also had previous experience of using an interpreter in challeng- 
ing conversations.

The study showed that those respondents who chose not to use an interpreter at first, still asked the interpreter about questions that either were difficult to understand or which required a more nuanced answer. Language is a strong bearer of identity, and therefore it was important for us to give the respondents the opportunity to express themselves in the language they felt comfortable with and with which they identified. This is also about showing respect for respondents.

Prior to the gathering of data, the project was reported to and approved by the Privacy Ombudsman for Research, the Norwegian Social Science Data Services (NSD). The study also required permission from the Ministry of Justice and Police and the Ministry of Education and Research. We did not incur any obstacles on this occasion. Prisons in Norway have adopted the socalled import model (Christie, 1970) for delivery of services to the prisoners. From this it follows that the normal school system will supply educational services in prison. The County Governor of Hordaland, Department of Education, is the organization in charge of Norwegian prison education, serving the Ministry of Education. Representatives of the Governor made the first contact with the prisons. When contact was first established, the project manager at the University of Bergen made appointments with each of the three prisons, where we were well received by the prison and school management.

\section{Analyses}

All interviews were transcribed in Norwegian, in the way the respondents' statements were formulated through the interpreter. We used the qualitative analytical programme NVivo9 to analyse the data. NVivo9 is a computer programme that automates many tasks that qualitative researchers usually do manually; such as classification, sorting, analysis and visualisation of text based data. This makes the scope of the data easier to follow and improves reliability of the analyses and the interpretation process.

\section{Results \\ Educational background}

The oldest respondents went to school in Iraq between 1970 and 1980 and generally have spent more time in education than those who were born later. The youngest members went to school after the heyday of the educational sector, and they left Iraq before the reconstruction of a new educational system started. With the exception of one respondent, they were all six years old when they started school in Iraq. The school year lasted eight months, and the normal school week was six days with Fridays off. Some respondents say that in addition to attending public school, they received education at the Koran school (madras) in the mosque in the afternoons. To the question of whether school was compulsory, answers varied. Some claimed that schooling was compulsory while others said the family decided whether the children should attend school or not. In many schools it was the practice that those who did not turn up to school were punished by being forced into military service by the Ba'ath party, which kept a close eye on the school system.

The respondents attended school from between 1 and 15 years. Two have formal education beyond upper secondary level: one is a trained practical nurse; another completed the military academy in Iraq. Only one of the respondents had completed secondary education in Norway, but he had only three years of schooling behind him before he started secondary education. There is, however, great uncertainty associated with these figures, and many of the respondents seem unsure about the exact number of years they have attended school in Iraq. Several of them have had large gaps in their schooling. For example, one respondent had an interrupted school education but then spent two years at a maritime college in another country before coming to Norway. Some may have had only a few months active schooling but still declare it as one year. The figures we used depended on whether we looked at the number of years the respondent had actually attended school or the highest completed level of education. Even when seven interviewees declared that they have sat a final exam, only three of them have a certificate or other documentation of completed education in Iraq. When asked if they had a certificate, the respondent either replied "no", that they did not complete school or education, or that they sat exams but the certificate is missing. Most still emphasise that they want documentation of the education or training they are receiving in prison because it will help them when they are going to apply for work. For a couple of the respondents, it is the certificate itself that is the main purpose of the education.

While well-educated Iraqis tend to seek asylum in the UK and other European countries, those with lower educational background seem to choose Norway and other Scandinavian countries, as many believe that the Norwegian welfare system will provide better welfare conditions regardless of social, cultural, economic or educational background. Many of them come from the urban districts of Northern Iraq (Valenta, 2008).

What we can assume from these findings is that prisoners from Iraq lack formal documentation of completed schooling and education in the form of a certificate or other documentation. This makes it difficult for those who are responsible for adapting the curriculum and the courses to the needs of the individual prisoner.

\section{Education in a country interrupted by war}

Something that emerges in several interviews, especially with the older respondents, is the negative influence the authorities had on the education system. A great deal of the education was aimed at indoctrinating the pupils and securing their loyalty: “...we received a lot of education in Saddam's ideas". There were stories of young people who, for different reasons, had their schooling and educations interrupted and were forced into military service. Others dropped out of school and studies to join resistance movements in the mountains.

In addition to the more structured questions, we encouraged the respondents to tell us something about 
their time at school in Iraq. It emerged that positive and happy memories were associated with the breaks and the time spent with friends: "We had a lot of fun, with both friends and teachers." When we asked the respondents about negative experiences during their time at school, many tell us about physical abuse by the teachers; being hit and kicked if they could not answer questions or when they had not done their homework.

I had a ring on my finger. Once my teacher hit me it broke. I hated school after that. The school teachers are good at finding different ways of hitting us.

Some said that one of the reasons they took care with their school work and homework was to avoid being hit by the teacher:

We had a mathematics teacher who died. He hit us more than normal. He didn't hit us on the hands, but he took our shoes off and hit us on the feet. I learned maths because he hit us. I studied maths a lot because I didn't want to be hit.

War and political conflict make up the framework around all the respondents' stories about schooling. To many it has meant fear, an insecure financial situation, moving, interrupted schooling and great difficulties with concentration. The consequences the war had for the individual vary, but none are unaffected: "There is nobody from Iraq who doesn't have sad memories." Many tell us that the war was a feature of the school days and they often had to hide in basements for protection. Bombing took place at different times of day because "the war did not keep regular hours":

When the planes arrived from Iran everybody had to run. There was a big hole dug under the ground and we crept into the hole and hid. At that time there were only problems and I was always afraid.

Flight seems to be a central feature of the respondents' stories. They told us about interrupted schooling because their families have had to flee, either internally in their own country or to other countries: "It was a war situation. We were almost always on the run, from one place to the next. The city was bombed and the teachers were afraid to come to school". With the exception of the two respondents who received most of their education in Norway, none of them say they quit school because it was boring or that they didn't like going to school. The reason for interrupted schooling seems to have been growing up in a country at war, and where war for different reasons made it difficult to complete one's education or maintain a normal progression of the school trajectory. Given the highly unpredictable life and educational situation, some fled from Iraq without resuming their schooling in the country they came to.

The interrupted, and for some respondents, traumatic educational background often makes it difficult to start, resume or fulfil educational activities in prison. But most worrying though is the lack of educational opportunities in prison which we will see from the following section.

\section{Educational activities in prison}

In this part we take a closer look at the ongoing formal educational activities in which respondents partici- pate, or expect to start while serving their sentence. Seven respondents have taken courses during their sentence or are taking courses arranged by the prison education service, such as Norwegian, English and the Computer Driving Licence. Furthermore, two respondents have started vocational training such as carpenter and chef courses. To complete a course of education to the level of certificate of apprenticeship they need an apprenticeship which might be a difficult to secure. For the respondent who is training to be a chef, the road to an apprenticeship depends on the court cases awaiting him and the prison in which he will serve his sentence. Those who take courses or vocational education are generally positively disposed towards their training, but many point out that it would be better to have more hours per week devoted to the courses they are taking. The hours studied are often not enough to reach a quality education. There are also too few offers for prisoners, and it would be beneficial if the educational offers available were more extensive. Educational possibilities for the prisoners depend to a great extent on the offers given in the particular prison they serve their sentence. A prisoner can only become a carpenter if this is an educational offering in that particular prison. There is variation regarding which and how many educational activities the prisoners take part in. It ranges from taking a vocational education course, such as carpentry, to not participating in any form of organised education or training. Most respondents complain about the lack of information and long waiting lists for a place at school, but nevertheless most of them take part in some activity or another. If they did not get a place on a course or education programme in prison, they talked about activities they are involved in on their own. This could be reading (technical literature, poems, history, religion, and entertainment), writing (poems, songs, and stories), drawing or other activities they engage in to pass the time. Some prisoners mentioned books they had obtained from the library or borrowed from others. Some also say they borrow books to learn Norwegian or children's books that are easier to understand.

Lack of courses and long waiting lists may be frustrating but, as we have seen, it also stimulates creativity and individual initiatives.

\section{Educational preferences}

In the following section we present the respondents' educational preferences in prison. The majority of the respondents want to get an education or receive training in prison. Many say that the main aim in terms of education is to get a master's degree, or become a doctor or teacher, but that these dreams are difficult to fulfil. The respondents primarily want two kinds of courses, computer driving licence and language courses in Norwegian and English. In addition there are some who want vocational training, to obtain jobs such as chef, hairdresser or car mechanic. The preferred vocational education and training is not possible to achieve in all prisons, so the prisoners are dependent on moving to a prison that offers such courses. 
Most respondents say that improving their Norwegian language will make them more independent in Norway: "One can make enquiries for oneself without being dependent on others". Several of the respondents have had deportation orders imposed on them, but despite this, they envisage that they will return to Norway and have to learn Norwegian. However, one of them said that English will be more useful if he is going to be deported, because English can be used in many countries. One of the respondents, who had tried hard to get a place on a Norwegian course and finally had been told he had a place, is still waiting for an answer from the prison to see if he can accept the offer from the local authority:

I have some problems here in the prison, but I don't know if that is the reason I can't get an answer. I applied for a Norwegian course. I phoned the municipal authorities and they said it was free. Then I spoke to the prison about getting the time to go to school and learn Norwegian. I have not had an answer yet.

The reason given for learning Norwegian, English and computer skills is that it will make them better able to manage in Norwegian society. Should they be deported from Norway, they feel they have a better chance on the employment market in Iraq if they have digital skills and speak English as well. Generally it will help them in their job search if they also have a certificate or course diploma.

Several respondents, waiting for a place in school or a course, have tried to learn languages on their own, either alone in their cell or by talking to other prisoners. Two respondents say that they have obtained textbooks and that they are working regularly on their own: "I have to learn Norwegian; everybody likes speaking Norwegian, so I've been learning the language. I have bought 'Ny i Norge' and I've been self-studying." ("Ny i Norge", or New in Norway, was published in the early 1990 s and is one of the first introductory books for foreigners to the Norwegian language.)

Another says he reads children's books to learn more Norwegian, and he is working with "Word" on the computer and uses a dictionary. When asked whether he can get access to CD-ROM where he can listen and watch pictures, he says this is not available in the prison and he would have to get it himself. The prisoners are generally unsure of what is available in terms of teaching aids in prison and what they are entitled to, details that seem to unnecessarily impede studying on their own.

\section{Future outlooks}

It is clear that topics relating to the future, such as job plans, are difficult for the respondents to talk about because they consider them as unrealistic dreams: "I want many things, but since they are only dreams, I can't say them out loud." The time in prison complicates the future planning and it is difficult to imagine an existence outside the walls. Uncertainty about whether they will be allowed to stay in Norway or be deported makes it problematic to think about the future:
I believe that when you are in prison you don't think about the future. When I get out I can think about the future, but I still don't know if they are going to send me back or if I am staying here.

What am I thinking? I have no thoughts. I can't say anything because I don't want to think about any thing. I have no power over anything, right?

They rather prefer to think about the future when they have finished their sentence: "If I go back, I will do my thinking there, I can't think about that future now." Some people think it can be difficult to get work after spending time in prison and feel that nobody needs them: "I don't know what my future will bring; I don't know what will happen to me, I'm just sitting here thinking that after four years they don't need me." Others say that the world outside the walls has changed a lot during the time they have been inside and they think it is difficult to plan or envisage a future they are not in control over.

All respondents want to work when they are released. The need to look after themselves, their girlfriends, wives and children is an important motivational factor to get work. The gap between previous work experience in Iraq and Norway and the work they want in the future is not that great. Most prisoners want to continue with the same type of job they had previously: "If I return I want to do the same type of work I had before - construction work".

Five respondents have definite plans for what they will do after release. Of these, four have partially begun, are nearly ready or have completed their professional education as carpenters, welders, nurses and seamen. These have a strong preference for finding work corresponding to their education.

The respondents who do not have education see different job possibilities, but preferably connected to previous work experience in the area of car mechanics, restaurants and other service industries. Insufficient information and a lack of knowledge about the labour market and work opportunities within different branches in Norway, makes it difficult to plan what work they would like: "I want to be very involved with computers, but I don't know what job will be suited to that". Some consider that it won't be difficult to get a job after serving their sentence because they "know somebody" who can help them. They feel that family and friends are important resources in the search for future work. Only one of the respondents says that he will go through a recruitment agency to look for a job. Otherwise some individual prison officers and the social welfare office are helpful in contacting employers when the prisoners have served their sentence. The respondents who, due to deportation decisions or for other reasons, envisage their future in Iraq, say that they will get work in relatives' businesses there: "I have a father, mother and brothers who will help me".

Even if some respondents are currently taking an education in prison or follow courses and training, it is clear that many regard education and training more as a dream than a realistic possibility. Even if some have thoughts about what they would want if their situation 
had been different, they are also sufficiently focused on reality to understand that this would probably not be possible.

Given the structural framework in the prison and the fact that a large number of them have been away from school for a long time, many of the respondents do not have great hopes of realising their educational preferences.

\section{Obstacles to participating in educational activities}

The majority of the respondents felt they received little or no information about the prison education services or educational activities in prison. We know that a brochure about educational opportunities for prisoners is distributed to prisoners, but for different reasons, such information is often completely lost. Information about educational opportunities is available in Norwegian and English. It is therefore quite likely that some foreign prisoners do not understand the information they receive.

Even if the respondents want an education while in prison they say there is a long waiting list, a lack of course places, that they get started late and that complaints and requests do not get through. "I filled out an application for a school place but they said there were no places available. Instead I got a job." Another prisoner says: "I applied for a Norwegian course but after six months there is still no answer."

Many say that they have already "ticked the box on the form", but have been told to wait without receiving any information about what is happening with their application in the meantime. Common to all the respondents is that they do not know why or for how long they must wait for an answer. They have waited from a few months to a year and they do not feel they have any influence on the situation. One respondent asked the prison officers and the educational staff several times when he could expect to get a place on the course but was told they didn't know, or "that's the way it is in prison". Another respondent was told that prisoners were not entitled to education when it had been decided to deport them. "The last message I received was that prisoners with expulsion decisions have no right to education or to attend courses."

Many say that they have already "ticked the box on the form", but have been told to wait without receiving any information about what is happening with their application in the meantime. Common to all the respondents is that they do not know why or for how long they must wait for an answer. They have waited from a few months to a year and they do not feel they have any influence on the situation. One respondent asked the prison officers and the educational staff several times when he could expect to get a place on the course but was told they didn't know, or "that's the way it is in prison". Another respondent was told that prisoners were not entitled to education when it had been decided to deport them. "The last message I received was that prisoners with expulsion decisions have no right to education or to attend courses."

Through our conversations with prisoners during this study, it is clear that some are in need of psychological counselling services. However, none of them told us that they are getting help with processing thoughts and experiences in prison or that anyone has looked at their background related to previous education and work experience.

\section{Discussion}

Iraqi prisoners constitute one of the largest groups of foreign prisoners in Norway. In the study 17 of them were interviewed about their educational background, educational wishes and barriers against starting an education while incarcerated. In the following section some of their past and future educational challenges will be discussed.

\section{Educational background as interrupted by war}

Iraq as a state has been characterised by war and political unrest for several decades; this has affected the infrastructure and the society as such in negative ways, not least the educational system. According to Hanemann (2005), war and political conflict have destructive effects on education and literacy, both in terms of the suffering endured and psychological effects on pupils and teachers. An important finding in this study, although hardly a surprising one, is that war and political unrest appear to have been significant causes for respondents leaving education at various stages. As a result only half of the respondents have completed just one final exam, and only three respondents have a certificate of education. In contrast, only seven percent of prisoners with Norwegian citizenship have not completed any education (Eikeland et al., 2013).

One consequence of war-related traumatic situations is that many have problems with concentrating on learning activities. It is a fair assumption that as pupils they have had a difficult basis for learning and education. According to our knowledge there is currently no tool in use to map foreign prisoners' competencies, strengths and weaknesses with regard to education that can facilitate adapted educational activities. This clearly shows that before a minority prisoner is enrolled in prison education, the school administration or the teacher should conduct a first meeting with an intention to map the prisoner's education history, wishes and reported needs. This presupposes that educational staffs have gained knowledge about the prisoner's country of origin, the political, socio-cultural and educational system there. If the first meeting is held in an atmosphere of confidence there is a fair chance that the prisoner will provide the necessary information so as to enable the staff to adapt the educational programme to the particular prisoner's wishes and needs.

Many prisoners report knowledge or possess competence regarding issues that the prison might oversee. One such circumstance that was highlighted during the interviews is foreign language. The majority of the respondents say that they speak one or more foreign languages. However, it is not clear whether they can read or write these languages or if they only communicate verbally. Nevertheless, this indicates that the prisoner 
has the ability to learn a language, a factor that can also be used as a motivation when they start to learn the Norwegian language. Also Linderborg (2012) showed in his qualitative study of Russian prisoners in Finland that many of them were highly competent and had formal education equivalent to the normal population. Again, this indicates the necessity of having knowledge about the prisoner's background and his wishes for education in prison.

In Iraq every child who was enrolled in school started their education in Arabic which was the official language also in school at the time. For many pupils with a different mother tongue, education in a foreign language resulted in a major setback. The majority of the respondents in this study spoke Kurdish, which meant that they had their first educational learning experiences in a language forced upon them by an authority that they regarded as the enemy. As language and identity are closely connected, the motivation and ability for learning in a foreign language were low for many of the respondents. Some dropped out either because it was difficult to understand what was going on in class or as a form of resistance. After 2003 Kurdish and other minority languages, in addition to Arabic, have become the main languages of instruction in schools in North Iraq.

Competence in Norwegian is a precondition for following and completing education in prison. However, in general the respondents' ability to function in Norwegian is poor. It appears that they understand, read and write more Norwegian in relation to close personal relations and social contexts. Almost without exception the respondents can see advantages of learning Norwegian. Some of them have borrowed teaching material for Norwegian language courses (Ny i Norge) or children's books. Some respondents have already completed Norwegian courses, while many say they have registered for such courses without being offered a place. Due to their low level of competance in Norwegian, many prisoners will require Norwegian training, both in order to benefit from the education and training services and also to be able to communicate with other prisoners and prison personnel. The prisoners 'Norwegian language skills should be assessed immediately on arrival so that they can be given an offer of Norwegian courses adapted to their levels and abilities, and even literacy courses if deemed necessary. It is of considerable concern to experience how many prisoners have problems with reading and understanding letters from public offices. If they are going to stay in Norway it is crucial that they are able to understand what public offices try to communicate to them. Gustavsson (2012) also shows in her study of Serbian prisoners in Sweden that Swedish courses increased their possibilities for understanding information provided and its contexts.

One may assume that at least some of the respondents have such poor literacy skills, perhaps also in their mother tongue, that they can be categorised as functionally illiterate. That means that they can read and write enough to manage everyday life, but do not have the literacy skills to take control of their life situation.
UNESCO (2003) has concluded that six to eight years of schooling is a minimum in order to function in modern society. Many respondents do not have these many years. If this group of prisoners develop knowledge and skills in Norwegian, both spoken and written, it will increase the chances of employment for those who are going to stay in Norway.

\section{Educational preferences and needs}

The respondents in this study expressed many wishes, or rather dreams about education, both in Iraq and Norway. One significant motivational factor for the desire for education, training or work is the possibility of being able to take care of family and children in the future. Their preferences for training or education appear to be highly correlated to their past work experience. Some of the respondents have started or would like a vocational education, such as mechanic, chef, hairdresser, or other occupations. Minority prisoners, who are "sure" to be deported, want courses in English and vocational training because it will benefit them when they return to Iraq.

As a result of a poor educational background, many of the respondents think they will need support during their education and training in prison. This is especially the case with respect to the general school disciplines. Looking at the general level of education among the group of respondents, it is likely that many of them will have need for extensive help if they are going to have a real chance of taking and completing education and training during their sentence, or find work after they have served their sentence. NAFO (2009) has developed an action leaflet for training of prisoners with minority languages within the criminal administration system. The measures appear to meet some of the needs expressed by the respondents in this study. For example, NAFO emphasises the importance of a thorough study of the prisoners' language skills and total qualifications, crucial for being able to adapt the teaching and training for this group of students.

In order to take an active part in Norwegian Society, most people need basic digital competence. Thus the prison authorities must prepare a strategy for how ICT can be developed and implemented in education and training in prison. This is also a challenge for democracy. The Report to the Parliament (Storting) no. 37 (2007-2008) from the Norwegian Ministry of Justice and Police (2008) states:

The Ministry aims to establish internet for prisoners in all prisons. Internet will enable better availability of learning opportunities and increase the possibili ties of taking higher education at technical college and university level. As well as being important for teaching and learning, internet is a social benefit that breaks down the barriers between prisoners and the wider society. Ethnic minority prisoners can have the opportunity to read the newspapers from their own country in their own language. Access to internet is a necessary service if the principle of normal ity is to be followed (p. 112).

Previous surveys of prisoners, in Norway and in the 
Nordic countries (e.g., Eikeland et al., 2009), show that there is insufficient access to ICT equipment in prisons. This creates problems and obstructs education and educational progression. Most respondents in this study express the same meaning. They are frustrated because they don't have, or only have limited access to the internet and ICT based tools in prison. Many also want CD-ROM with educational content so they can teach themselves. But because this appears to be difficult in prison, they borrow educational material, which to some extent appears to be obsolete.

\section{Barriers against education in prison}

As an additional element of the discussion we will highlight some of the structural barriers that the respondents consider significant obstacles to starting and completing education in prison.

If the prisoner manages to find out what education and training opportunities he has, it appears that the waiting time is inappropriately long before they are offered a place at school. The waiting period according to some informants lasted almost a year. This is in agreement with findings by Ravneberg (2003), who says there is no uniform practice for how the prison authorities inform the prisoners of their educational and training opportunities, but that this varies from prison to prison. It also emerged that there could be a long period from the prisoners starting their sentence to commencing education, work or future planning. A common experience in the present study and in the four other groups of foreign prisoners that were interviewed in the Nordic studies of ethnic minorities in prisons in Denmark, Finland, Iceland and Sweden, is that the prisoners are not given a reason for the long waiting time (Gustavsson, 2012; Linderborg, 2012; Kristmundsson, 2012; Thomsen \& Seidenfaden, 2012). This creates unrest and suspicion that the waiting time is deliberately prolonged by the prison. It is not clear to the researchers what the real reason for the waiting time is. Are there not enough places on the individual courses? If this is due to inertia in the system, then where are the bottlenecks? Contrary to the foreign prisoners in both this study and the study of prisoners from Lithuania, Poland and Nigeria in Norwegian prisons (Eikeland et al., 2014) only 13 percent of the Norwegian prisoners, who do not participate in education, say that the reason is that they are waiting for a school place (Manger, Eikeland, Buanes Roth, \& Asbjørnsen, 2013). In both these studies about 20 percent of those who have not started an education prefer work and not education.

Interrupted education or training, as a result of being moved to other sections or prisons, is one example that the respondents point to. Another barrier that is mentioned is that information leaflets about education and training opportunities in prison are only available in English and Norwegian. In a new study (Thorsrud, 2012) on women in Norwegian prisons, it is claimed that the criminal administration system faces great challenges in relation to communicating with and providing information to prisoners with minority languages $^{2}$. It emerged that prisoners who do not speak
Norwegian miss out on important information due to language problems. This leads to frustration and poses a risk that the interests of the prisoners are not taken care of. Findings from the five national surveys in the Nordic countries show clearly that the biggest obstacle for starting an education in prison appears to be a lack of information or inadequate information in their mother tongue (Eikeland et al, 2009). Also in the current study it emerged clearly that different practices regarding information, interpreting and written material cause problems for the respondents. The Educational Act recognizes the right of basic schooling for all, and all teenagers and adults who have completed compulsory school have a right to three to five years of upper secondary education. Adults also have the right to "second chance" or supplementary basic education and/ or special education. As of today education is provided in all Norwegian prisons (Eikeland et al., 2014). Ethnic minority prisoners in Norwegian prisons have rights relating to education and of course other measures. However, it turns out they often do not know what rights they have. The rights are often not clearly stated and are practiced differently in prisons and in the criminal administration system. With respect to the right to information and interpreter services in their own language, it appears that this is provided only to a very limited extent. The flow of information from the prison to the foreign prisoner often appears arbitrary. If this is due to a lack of an information strategy, arbitrariness, indifference, discrimination or perceived language barriers on the part of the prison, we do not have any basis for commenting on, but statements by the respondents in the Norwegian material speak clearly. Information about the education and training services in prisons does not reach the prisoners to an adequate degree, and if it does, it is often in a language the ethnic minority prisoners do not understand. A prisoner must be able to express himself in the language he knows best, or understands. If this is not possible the communication must be done via an interpreter. Not only is it important that ethnic minority prisoners receive and understand important information, it is also important that they receive help with searching for the information they require. According to Skutnabb-Kangas and Philipson (1994), it should be a given that education and information are presented in the mother tongue.

A finding that is cause for concern is the fact that a large part of the information that is disseminated to the prisoners does not come from the staff of the prison or from teachers, but from other prisoners - usually from the same country. Associated with this practice there are legal, security-related and ethical problems. Neither does it guarantee that the information that is communicated is correct. On the contrary, it can be misunderstood, misinterpreted and incomplete. This could have consequences for whether the prisoner chooses to take part in educational activities in prison, and for what he chooses. Lack of information also deprives the prisoner of the opportunity to make a qualified choice as to educational activity. It does occur that the prisoners do not know they can take part in education in prison or what 
they can choose - such as the respondent who has a strong wish to resume previously interrupted studies, but says he didn't know there was such a possibility in the prison.

Decisions made by the prison, such as rejecting applications for permits, are written in Norwegian, while they should be written in the mother tongue of the prisoner or in English. This does not necessarily require a lot of resources and will protect the prisoner's legal rights in a much better way. There are many ethnic minority prisoners who do not master these languages or who could not read such information, even if it were available in their mother tongue. If the prison wants to reach the ethnic minority prisoners with information, it must be translated to the different languages of the prisoners. They must also be offered interpreter services or help to read the contents. Poor information about educational opportunities in prison results in insecurity about what the prison education actually has to offer. When such information is also presented in a language the prisoner neither speaks nor understands, then he is prevented from being able to take in the information and think about what offers are suitable for him or her. It becomes almost impossible to plan a course of education or training. It is also an infringement of their basic and legal rights to education and training. This is ethically difficult and unprofessional. It also creates the risk of a prisoner, acting as interpreter for another, gaining access to information that creates an imbalance of power between the parties. This can create unnecessary conflict between prisoners.

As we understand from the respondents, it is difficult to gain access to interpreter services in prison. Instead, other prisoners with the same language are used as interpreters. Another very unfortunate issue is the long waiting time to get a place in a Norwegian language course and other educational and training services in prison. The Iraqi prisoners in this study also experienced difficulties with making enquiries and were sometimes met with irrelevant and negative responses. Those with deportation decisions against them also feel that this is used against them with regard to education. According to Skarðhamar (2006), individual resources, such as education and participation in the job market, are important for facilitating individual development. Skarðhamar claims there is little doubt that some immigrant groups generally are more exposed to certain factors associated with crime. At the same time the tendency in his material shows that if education and training are facilitated, many of these groups will do well in Norway. One important premise is that the time during their sentence is used to prepare the prisoner for the time after release. In this context that means giving the prisoner a place on a Norwegian language course and that their educational or training preferences are realised as far as possible. With the necessary support most can manage to qualify according to their abilities.

During their time in prison the prisoners have a need to communicate with staff, as well as with other prisoners. If they commence an education in prison, they must have sufficient language skills to understand what they are reading and to be able to solve problems. The problem seems to be that it is difficult to get entrance to the language courses. If the prisoner has a deportation order against him, it appears somewhat arbitrary what educational activities they are entitled to and whether they manage to get a place in education and training at all. It is a problem when such ambiguity creates less favourable conditions for education and training for certain groups of prisoners.

\section{Conclusion}

Norwegian prisons today are multicultural, but the educational services are still organised as if the prisons are monocultural. The criminal administration system and the educational authorities in Norway must take into account the multicultural reality by facilitating education and training offers accordingly. This does not just apply to language courses; it must apply to all subjects and courses that the prison offers. The respondents follow the courses the actual prison offers and that largely means activities covered by the staff's professional competence, unless ICT-based teaching is offered. It goes without saying that if the staff's professional competence determines what is offered, this can be too limited in relation to the diverse requirements of the prisoners. The 17 respondents in this study come from Iraq, though the majority come from the autonomous Kurdish region in Northern Iraq. Their early childhood and educational history were disrupted by internal war, suppression and political conflict, followed by invasion by external powers in 2003. Even if they share some common experiences, the respondents in the study have different backgrounds, education and work experience and thus different preferences for education in prison or after their release. The majority of the respondents believe they need more education to do well in the job market, even if they also consider their chances small because they have a criminal sentence behind them. They want more educational options and shorter waiting time to get access to the various educational activities. However it seems that the practical organisation of the educational activities, like the lack of access to a student advisor or counsellor, prevents participation and completion.

Today, every prison in Norway has a highly diverse population, which must be taken into account when educational activities are being organized. Although there are educational programmes in all Norwegian prisons, there is no current coordinated plan for education and training for minority prisoners, which creates more disruption, interruption, and loss of motivation. One serious concern related to this is the lack of information in the prisoners' mother tongue in addition to the use of fellow prisoners as translators and interpreters. In a larger way, the prison and probation services and the educational authorities must make regular surveys of prison populations, identify needs, and see to it that the educational activities offered are kept in line with these needs. Especially, it is important to analyse the educational needs of prisoners who belong to subgroups that are culturally distant from the dominant 
culture. The criminal administration system and the school have to gain knowledge about their previous educational background and put it in context. It is a matter of concern that so many of the ethnic minority prisoners have a need for elementary education which is a necessity for having a real possibility for further education, work and social interaction when returning to society. The correctional service, teachers in prison and prison staff can make a significant difference to the foreign prisoner's motivation for education and training but they must have competence in multicultural education. Our study indicates that so far the prison education is not able to meet the major challenges the prisons are facing when it comes to diversity. According to the Education Act students in upper secondary school are entitled to adapted education. Despite this, students in prison and in particular ethnic minority students, seldom benefit from this. Most teachers in Norway are not prepared to face the educational challenges in diverse class rooms. One important policy implication is that future and present prison teachers should be given education, training and support to deal with the great diversity in the prisoners' educational background, ethnic belonging, language, religion and culture.

If there is to be any hope for this group of ethnic minority prisoners from Iraq getting the education they are entitled to under Norwegian law, international conventions and the legal principle of equality for individuals in equivalent situations (e.g., Norwegian and foreign prisoners in the same prison), the prison and schools have to acknowledge and relate to the multicultural reality they are part of and adapt the educational services accordingly. The prison is a closed institution, but it is also part of the society to which the prisoners are returning.

\section{Acknowledgments}

We would like to express our gratitude to the County Governor of Hordaland, Department of Education, for the initiative and support for the project. Thanks also to senior consultant Torfinn Langelid, senior consultant Gøril Vikøren Nøkleby and senior consultant Paal Chr. Breivik for their coordination of the work. Great thanks also to the interpreter Nizar Hirori and research assistant Kristine Ludvigsen (University of Bergen). Last but not least, we would like to thank all employees of the prison services and schools who facilitated the survey and the inmates who answered the questions willingly and enthusiastically during the interviews.

\section{References}

Achermann, C. (2009). Multi-Perspective Research on Foreigners in Prisons in Switzerland. In A. V. Liempt (Ed.), The ethics of migration research methodology: dealing with vulnerable immigrants (p. 42-80). Sus sex: Academic Press.

Bosworth, M., Campbell, D., Demby, B., Ferranti, S. M., \& Santos, M. (2005). Doing prison research: Views from inside. Qualitative inquiry, 11(2), 249264.

Bush, K., \& Saltarelli, D. (2000). The Two faces of education. Towards a Peacebuilding Education for Children. UNICEF Innocenti Insight, Florence, Italy. Christie, N. (1970). Modeller for

fengselsorganisasjonen. I stedet for fengsel [Models for the prison organisation. Replacement of prisons]. Oslo: Pax.

Davis, L.M., Bozick, R., Steele, J.L., Saunders, J., \& Miles, N.V. (2013). Evaluating the effectivness of correctional education. A meta-analysis of programs that provide education to incarcerated adults. Santa Monica, CA: Rand Corporation.

Eikeland, O.-J., Manger, T., \& Diseth, A. (2006). Innsette i norske fengsel: Utdanning, utdanningsønske og rett til opplaring [Inmates in Norwegian prisons: Educational background, educational aspirations and right to education]. Bergen: Fylkesmannen i Hordaland, Utdanningsavdelinga.

Eikeland, O.-J., Manger, T., \& Asbjørnsen, A. (2010). Innsette i norske fengsel: Kompetanse gjennom utdanning og arbeid [Inmates in Norwegian prisons: Competence, education and employment]. Bergen: Fylkesmannen i Hordaland, Utdanningsavdelinga. Eikeland, O.-J., Manger, T., \& Asbjørnsen, A. (Eds.) (2009). Education in Nordic Prisons. Prisoners' educational backgrounds, preferences and motivation. Copenhagen: Nordic Council of Ministers.

Eikeland, O.-J., Manger, T. \& Asbjørnsen, A. (2013). Nordmenn i fengsel: Utdannning, arbeid og kompetanse [Norwegians in prison: Education, work and competence]. Bergen: Fylkesmannen i Hordaland, Utdanningsavdelinga.

Eikeland, O-J., Manger, T., Grøning, L., Westrheim, K., \& Asbjørnsen, A. (2014). Innsatte fra Litauen, Polen og Nigeria: Utdanning, arbeid og kompetanse [Inmates from Poland, Lithuania and Nigeria:

Education, work and competence]. Rapport 1/2014. County Governor of Hordaland.

Gustavsson, A.-L. E., \& Samuelsson, S. (2007). Kartläggning av intagnas utbildningsbakgrunn studiebehov [A mapping of inmates' eductional background and educational needs]. Rapport 24. Linköping universitet.

Hanemann, U. (2005). Literacy in conflict situations. Paper commissioned for the EFA Global Monitoring Report 2006, Literacy for Life. Commissioned through the UNESCO Institute for Education (UIE). Retrieved 22 April 2008, from http:// portal.unesco.org/education/en/ files/43180/11327100211Hanemann_Literacy_con flict.doc/Hanemann_Literacy_conflict.doc Henriksen, K., Ostby, L., \& Ellingsen, D. (Red.) (2010). Innvandring og innvandrere 2010 [Immigration and immigrants 2010]. Statistisk Sentralbyrå/Statistics Norway. Oslo-Kongsvinger. Retrieved 11 March, 2014, http://www.ssb.no/sok? hovedemner $=$ Innvandring + og + innvandrere $\&$ sok $=$ inn vandring

Høstmælingen, N. (2004). Internasjonale menneskerettigheter [International human rights]. Oslo: Universitetsforlaget.

Issa, J. H., \& Jamil, H. (2010). Overview of the Educa- 
tion System in Contemporary Iraq. European Journal of Social Sciences, 14(3), 360-386.

Kristmundsson, G. B. (2012). Polske indsatte i Island [Polish inmates in Iceland]. I K. Westrheim og T. Manger (red.). Utdanning, kompetanse og motivasjon for utdanning. En kvalitativ studie av innsatte fra Irak, Polen, Russland, Serbia og Somali. Bergen: Fylkesmannen i Hordaland. Utdanningsavdelingen, s. 97-112

Liebling, A. (1999). Doing research in prison: Breaking the Silence? Theoretical Criminology, 3(2), 147-173.

Linderborg, H. (2012). Ryska intagna i Finland [Russian inmates in Finland]. I: K. Westrheim \& T. Manger (red.), Utenlandske innsatte in nordiske fengsel. Utdanning, kompetanse og motivasjon for utdanning (s.69-96). Bergen: Fylkesmannen i Hordaland, Utdanningsavdelinga.

Lowman, J., \& Palys, T. (2001). The ethics and law of confidentiality in criminal justice research: A comparison of Canada and the United States. International Criminal Justice Review, 11, 1-33.

Machel, G. (2001). Impact of war on children: a review of progress since the 1996 United Nations Report on the impact of armed conflict on children. London: $\mathrm{C}$. Hurst \& Co Publishers Ldt.

Manger, T., Eikeland, O.-J., Diseth, Å., Hetland, H., \& Asbjørnsen, A. (2010). Prison inmates' educational motives: Are they pushed or pulled? Scandinavian Journal of Eductional Research, 54, 535-547.

Manger, T., Eikeland, O.-J., Roth, B.B. \& Asbjørnsen, A. (2013). Nordmann i fengsel: Motiv for utdanning [Norwegians in prison: Motives for education]. Bergen: Fylkesmannen i Hordaland,

Utdanningsavdelinga.

Nasjonalt senter for flerkulturell opplæring (NAFO) (2009). Idehefte. Tiltak for språklige minoriteter innenfor kriminalomsorgen [Help to language minorities in the Prison and Probation Services]. Oslo: NAFO.

Newman, D. J. (1958). Research interviewing in prison. The Journal of Criminal Law, Criminology, and Police Science, 49(2), 127-13.

Norwegian Ministry of Justice and the Police (2008). Straff som virker - mindre kriminalitet - tryggere samfunn (kriminalomsorgsmelding).

NOU 2011: 14. Bedre integrering. Mål, strategier, tiltak [Better integration: Aims, strategies and implications]. Oslo: Barne-, likestillings- og inkluderingsdepartementet.

Quina, K., Garis, A. V., Stevenson, J., Garrido, M., Brown, J., Richman, R., Renzi, J., et al. (2007). Through the Bullet-Proof Glass: Conducting Research in Prison Settings. Journal of Trauma \& Dissociation, 8, 123-139.

Ranjan, R. K., \& Jain, P. C. (2009). The Decline of the Educational System in Iraq. Journal of Peace Studies, 16(1-2).

Ravneberg, B. (2003). Undervisning og opplcering i det moderne fengslet. Dannende eller disiplinerende? En undersøkelse av fengselsundervisningen $i$ Bergen og Oslo fengsel [Education in the modern prison:
Culture or discipline? A study of prison education in Bergen Prison and Oslo Prison]. (Rapport 5/03).

Rokkansenteret, Universitetet i Bergen.

Fylkesmannen i Hordaland.

Schlosser, J. A. (2008). Issues in Interviewing Inmates. Qualitative Inquiry, 14(8), 1500-1525.

Sheyholislami, J. (2010). Identity, language and new media: The Kurdish case. New York, NY: Springer. Language Policy, 9(4), 289-312. DOI 10-1007/ s10993-010-9179-y

Silverman, D. (2001). Interpreting qualitative data: Methods for analyzing talk, text and interaction (2. ed.). London: Sage Publication.

Skarðhamar, T. (2006). Ikke-vestlige innvandrere og kriminalitet [Non-Western immigration and crime]. Samfunnsspeilet. Oslo-Kongsvinger: Statistisk Sentralbyrå. Dato: 2006-10-09. 13:57 CEST.

Skutnabb-Kangas, T., \& Philipson, R. (1994). Linguistic human rights, past and present. In T. SkutnabbKangas \& R. Phillipson (Red.), Linguistic human rights: overcoming linguistic discrimination. Berlin: Mouton de Gruyter.

The Norwegian Correctional Services (2014). http:// www.kriminalomsorgen.no/utenlandskeinnsatte.237929.no.html

Thomsen, J.A., \& Seidenfaden, L. (2012). Somaliske indsatte i Danmark [Somalian inmates in Denmark]. I:K. Westrheim \& T. Manger (red.), Utenlandske innsatte in nordiske fengsel. Utdanning, kompetanse og motivasjon for utdanning (s. 43-67). Bergen: Fylkesmannen i Hordaland, Utdanningsavdelinga. Thorsrud, I. (2012). JURKS fengselsundersøkelse. En kartleggelse av kvinners soningsforhold i 2010/2011 [A mapping of womens' incarceration 2010/2011]. (Rapport nr. 62). Oslo: JURK (Juridisk rådgivning for kvinner).

United Nations Educational Scientific and Cultural Organization (UNESCO) (2003). Situation Analysis of Education in Iraq. Division of Educational Policies and Strategies. Paris. Retreived 11 March, 2014, unes doc.unesco.org/images/0013/.../130838e.pdf

United Nations, Economic and Social Council, Committee on Economic, Social and Cultural Rights. (1999). The right to education (Art. 13): 08/12/99. E/ C. 12/1999/10. (General Comments).

Viljugrein, T. (2002). Skole, språk og fengsel. Undervisning av mannlige minoritetsspråklige fanger $i$ fire norske fengsler [School, language and prison. Education of male minority language prisoners in four Norwegian prisons]. Bergen: Statens utdan ningskontor i Hordaland.

Yildiz, C. \& Bartlett, A. (2011). Language, Foreign Nationality and Ethnicity in an English Prison: implications for the quality of health and social research. Journal of Medical Ethics, 37(10), 637-640. doi:10.1136jme.2010.040931

Valenta, M. (2008). Finding friends after resettlement. A study of the social integration of immigrants and refugees, their personal networks and self-work in everyday life. PhD-thesis. Department of Sociology and Political Science Faculty of Social Sciences and 
Technology Management Norwegian University of Science and Technology, NTNU. Trondheim. ISBN 978-82-471-6518-8

Waldram, J. B. (1998). Anthropology in prison: negotiating consent and accountability with a "captured" population. Human organization, 57(2), 238-244.

Waldram, J. B. (2009). Challenges of Prison Ethnography. Anthropology News, 50(1), 4-5. doi:10.1111/ j.1556-3502.2009.05014.x
WES, (2004). Iraq: Education Overview. World Education Services. Nedlastet 28. november 2009 fra http:// www.wes.org/ca/wedb/iraq/izedov.htm

Westrheim, K. (2012). Demokrati i det flerkulturelle klasserommet [Democracy in the multicultural classroom]. I K.L. Berge \& J.H. Stray (red.), Demokratisk medborgerskap i skolen. Bergen: Fagbokforlaget, s. 206-224.

\footnotetext{
${ }^{1} 1$ January, 2012 the name was changed to Ministry of Justice and Public Security.

${ }^{2}$ The term minority language is used about children, young people and adults with a different mother tongue than the majority language. In most contexts in the report the term used is ethnic minority prisoners.
}

Kariane Westrheim, Ph.D., is associate professor at the University of Bergen. Her research publications and projects over the last five years focus on multicultural issues, knowledge and identity construction in social and political movements, and education in areas of war and conflict. She has conducted fieldwork in Turkey- Kurdistan, Iraq-Kurdistan, and European countries. From 2011 Westrheim has chaired a research project on foreign prisoners in Nordic prisons together with Professor Terje Manger at Department of Psychosocial Science, University of Bergen. The project investigates foreign prisoners' background, preferences and needs for education and training. In much of her work Westrheim's theoretical framework is inspired by critical pedagogy.

Terje Manger, Ph.D., is a professor in educational psychology at the Faculty of Psychology, the University of Bergen, Norway. He has published books and journal articles on topics such as general educational psychology, gender differences in mathematical achievement, motivation, self-concept and behaviour problems in school. Dr. Manger and his colleagues in the Bergen Cognition and Learning Group have a long record of contributions in the area of research on prison education and have the last years conducted several large scale studies in Norwegian and Nordic prisons. 